Article

\title{
Sustainable Agriculture Development in the Western Desert of Egypt: A Case Study on Crop Production, Profit, and Uncertainty in the Siwa Region
}

\author{
Noha H. Moghazy $1,2, *\left(\right.$ and Jagath J. Kaluarachchi ${ }^{3}$ \\ 1 Graduate Research Assistant, Department of Civil and Environmental Engineering, Utah State University, \\ Logan, UT 84322, USA \\ 2 Irrigation Engineering and Hydraulics Department, Faculty of Engineering, Alexandria University, \\ Alexandria 21544, Egypt \\ 3 College of Engineering, Utah State University, Logan, UT 84322, USA; jagath.kaluarachchi@usu.edu \\ * Correspondence: noha.moghazy@aggiemail.usu.edu
}

Received: 24 June 2020; Accepted: 10 August 2020; Published: 13 August 2020

check for updates

\begin{abstract}
The Egyptian government initiated a development project in 2015 to reclaim 1.5 million acres with the primary goal of increasing agricultural production. Siwa is one of these areas in the Western Desert of Egypt, with 30,000 acres using groundwater from the Nubian Sandstone Aquifer System (NSAS). This study investigates if government goals are achievable in the next 20 years to secure the food and water needs of the Siwa region. Results show that total required crop areas are 7154 and 6629 acres in winter and summer, respectively. These areas are less than 17,010 acres of available area for cultivation $\left(A_{V}\right)$. The estimated total water use is 40.6 million cubic meters (MCM), which is less than the $88 \mathrm{MCM}$ that is considered available groundwater in the Nubian Aquifer System (NAS). Due to available capacity in Siwa, an optimization model is used to maximize crop production considering government policies. The Autoregressive Integrated Moving Average (ARIMA) model was applied to predict production costs and sell prices of cultivated crops. Analysis included different scenarios beyond government-recommended approaches to identify ways to further expand agriculture production under sustainable conditions. Results provide valuable insights to the ability to achieve government goals from the project and changes that may be required to enhance production.
\end{abstract}

Keywords: Western Desert of Egypt; Nubian Sandstone Aquifer System; ARIMA; Siwa region

\section{Introduction}

The Nile River is the primary source of water in Egypt, which represents $94 \%$ of all renewable water resources [1]. Egypt is facing water scarcity where the population was 97 million and total renewable water resources was $570 \mathrm{~m}^{3} /$ year/capita in 2018 [2], which is below the water scarcity level of $1000 \mathrm{~m}^{3} /$ capita/year [3]. Most essential food products are imported, as production is insufficient to meet population needs. Self-sufficiency values of some strategic crops in Egypt from 2013 to 2017 are shown in Figure 1. These data show that self-sufficiency values of wheat, maize, broad bean, and barley are decreasing over time, where in 2017 these values are $34.5 \%, 47 \%, 30.7 \%$, and $86 \%$, respectively [4]. For sustainable socioeconomic developments in Egypt, water resources management is therefore important to protect limited water resources [5]. 


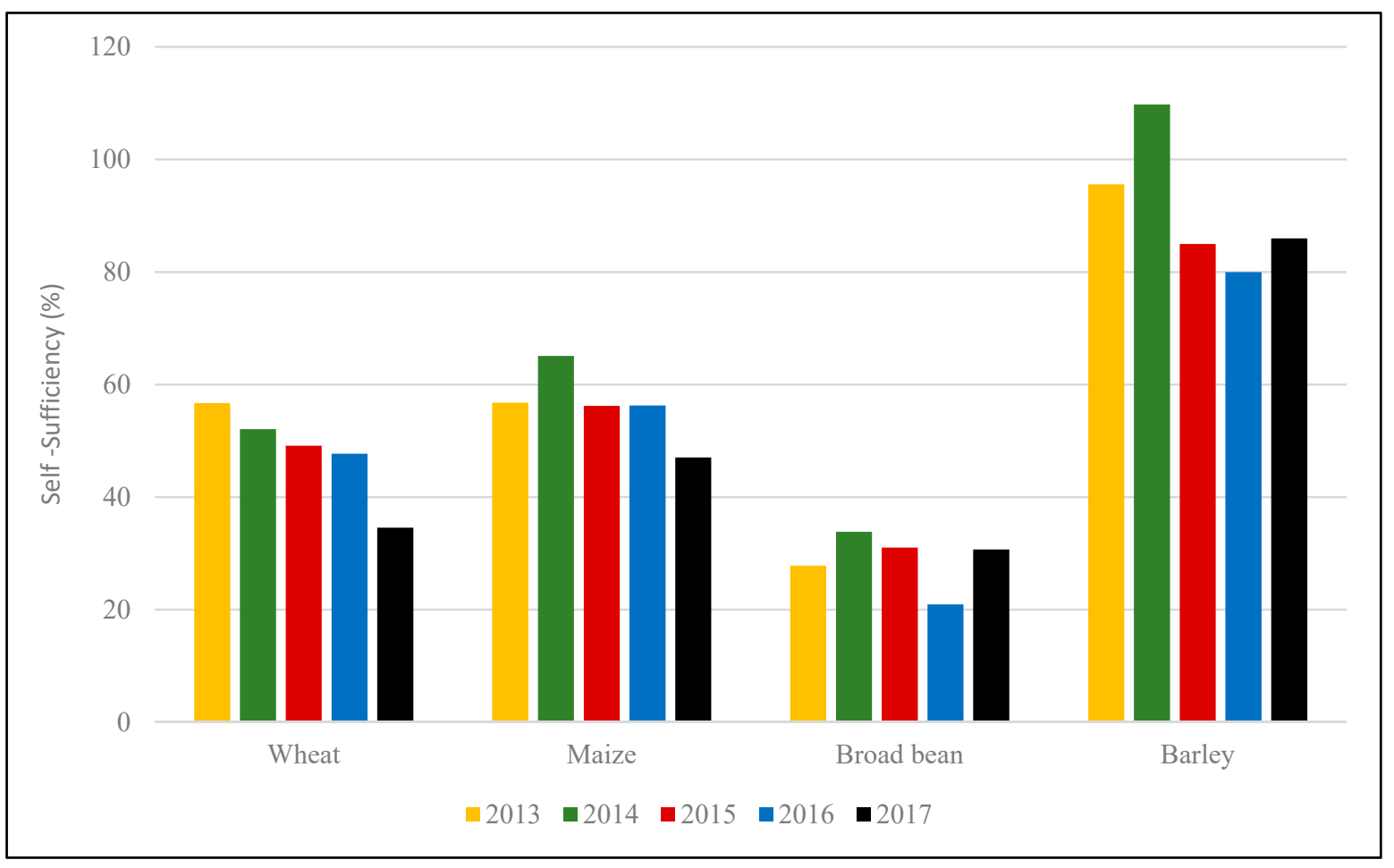

Figure 1. Self-sufficiency of selected strategic crops in Egypt [4].

The Egyptian Government always seeks alternative water resources and agriculture expansion projects to address some of these needs. In the $1960 \mathrm{~s}$, the government initiated a project in the Western Desert (see Figure 2) to increase agricultural areas and attract people from overpopulated regions. The primary source of water for this project was groundwater from the NSAS, which is a nonrenewable groundwater resource that is shared between Egypt, Libya, Sudan, and Chad. NSAS has two aquifers; the upper part is the Post Nubian Aquifer (PNA), followed by the Nubian Aquifer System (NAS), which has better groundwater quality [6,7]. NSAS in Egypt has a large volume of freshwater in storage which is $190,587 \mathrm{~km}^{3}$, while total recoverable groundwater is $5367 \mathrm{~km}^{3}$, assuming maximum water decline of $100 \mathrm{~m}$ in the unconfined aquifer and $200 \mathrm{~m}$ in the confined aquifer [7]. Groundwater withdrawals in Egypt are from different locations in the Western Desert such as the Siwa region (see Figure 2), which is the focus of this study given the abundance of groundwater from NSAS.

The major economic activity in Siwa is agriculture, while water-related issues have surfaced due to unmanaged groundwater withdrawal. Siwa has about 200 flowing springs, more than hundreds of poorly designed wells, in addition to six salty lakes [8]. Moghazy and Kaluarachchi [9] assessed the efficiency of groundwater use from the Nubian aquifer in Siwa and the corresponding negative impacts on crop yield and income from 1980 to 2012. The findings of this study showed that water use efficiency (WUE) was low at about 35\% from 1980 to 1998. However, the Research Institute for Groundwater (RIGW) of Egypt developed regulations in 1996 to limit groundwater withdrawal from the Nubian aquifer by closing some of the shallow wells and replacing others. As a result, WUE increased gradually to $94 \%$ by 2012 . These regulations were important to improve the conditions in Siwa, but the salty lakes in Siwa are still present due to the poor drainage system. Also, the use of groundwater from the PNA, which has high groundwater salinity around 3000 to $7000 \mathrm{ppm}$, decreased yields of two major cash crops, olives and date palms, by about $46 \%$ and $55 \%$, respectively from 2000 to 2011. As a result, net revenue of both crops decreased more than $60 \%$. 


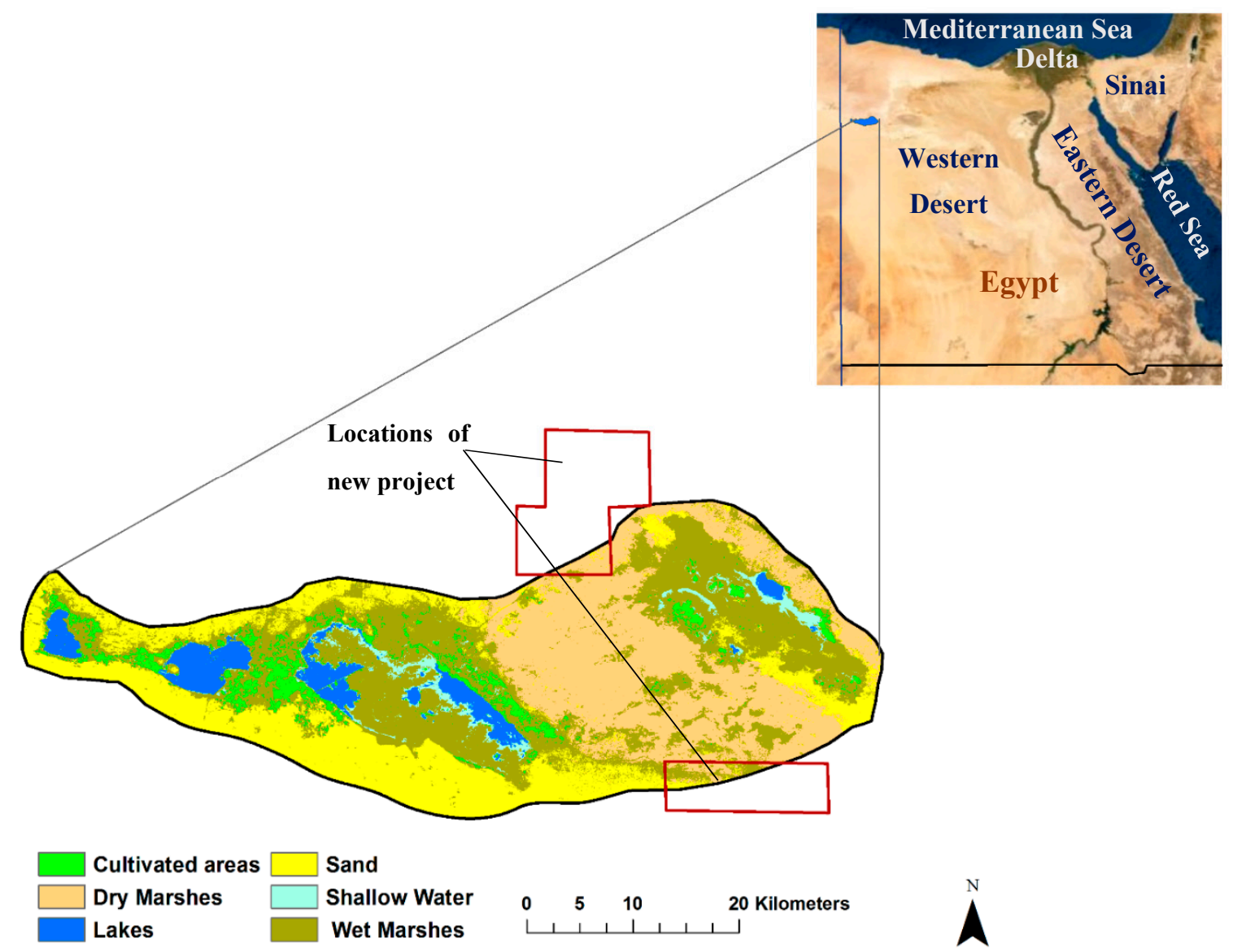

Figure 2. Physical description of the proposed reclamation project including the Western Desert and Siwa.

In 2015, the Egyptian Government initiated a national project to reclaim 1.5 million acres in 16 different locations of Egypt where most of the lands are located in the Western Desert region due to the large volume of groundwater available from NSAS. Due to the cost of this project, the work is be conducted in three phases with each phase consisting of 0.5 million acres. The Egyptian Countryside Development Company (ECDC) is responsible for managing this reclamation project (https://www.elreefelmasry.com). The goals of this project are to increase agricultural areas, increase crop production, decrease imported crops, population resettlement from the already over-populated Delta region, and increase investments and job opportunities. The Ministry of Water Resources and Irrigation (MWRI) has restricted policies to avoid significant depletion of this nonrenewable groundwater resource and to ensure the sustainability of the aquifer for future generations. The Siwa region is planned for the second phase to reclaim about 30,000 acres consisting of good soil quality [10]. Groundwater from NAS is used for development of Siwa given high water quality with salinity around 200 to 400 ppm [11].

Groundwater is the primary source of potable water in some countries, but there are challenges that affect sustainability due to population growth, climate variability, and land development [12]. AbuZeid and Elrawady [13] estimated the sustainability of NSAS under three different scenarios starting from 2008. In the first scenario, they assumed that the annual increase of population in Egypt is $2 \%$; total water available in Egypt, which is 57 billion $\mathrm{m}^{3}$ annually, is the primary source of water, and NSAS will be used to cover the shortage in water, and industrial and domestic water uses are $20 \%$ of total water available while agriculture will consume $80 \%$. The second scenario assumed a $2 \%$ increase in population in the Western Desert; NSAS is the only source of water, and agriculture will be the primary economic activity. In the third scenario, the assumptions are the same as in the second except that industry is the primary activity. Results showed that, in the first scenario, NSAS can be 
used for 60 years, and the expected area that can be cultivated is 39.3 million acres in 2068 with crop water use of $5000 \mathrm{~m}^{3} /$ acre/year. In the second scenario, NSAS can be used for 67 years with a total cultivated area of 32.5 million acres in 2074. In the third scenario, NSAS is sustainable for 119 years and the total cultivated area will be 22.4 million acres in 2126. As a result, the third scenario showed the availability of water from NSAS for 119 years, but with the least agricultural benefits.

Usually, agriculture developments face a problem of finding the optimal cropping patterns to obtain selected goals such as maximizing profit, minimizing costs, or maximizing production. Optimization is a method used to determine the best possible solution for a problem based on an objective with specific constraints. Sharma et al. [14] used a dynamic nonlinear programming model to analyze profit and risk of optimum cropping patterns under alternate policy scenarios in Himachal Pradesh, India. They found that relaxing some constraints can help increase income.

Since this national project has not commenced in Siwa yet, very little research and information are available. Therefore, this study addressed the development project in Siwa to reclaim 30,000 acres considering government policies in the next 20 years, assuming the project starts in 2020. Due to the available capacity of land and groundwater in Siwa, this study also explored additional strategies for sustainable agriculture developments by 2040 under current climatic conditions. One other goal of this work was to develop a suitable methodology and demonstrate its applicability in the Siwa region so that the methodology can be used in other regions of the Western Desert and other phases of this reclamation project.

\section{Study Area Description}

The Siwa region is located in the northwest area of the Western Desert in Egypt. It is a natural depression with an area of 0.28 million acres and an example of a closed basin where groundwater is the only source of water. Climate is arid to semiarid, where average annual rainfall is $13 \mathrm{~mm}$ and evaporation ranges from 5.2 to $17 \mathrm{~mm} /$ day $[8,15]$. Figure 2 identifies locations of the new proposed project in Siwa, which are away from the salty lakes and marshes.

RIGW [16] determined the groundwater potential from both aquifers in Siwa. It has been reported that, to ensure the sustainability of NSAS for the next 100 years, annual groundwater withdrawal should not exceed 60 and 88 million cubic meters (MCM) from PNA and NAS, respectively, where these values are small compared to the available groundwater in storage. Since this proposed new project in Siwa will use groundwater from NAS given high groundwater quality, a total of $88 \mathrm{MCM}$ of groundwater is available annually for development.

\section{Government Policies}

Restricted policies of MWRI include prioritizing water consumption from the nonrenewable NSAS to ensure aquifer sustainability. Some of these policies are as follows. The maximum discharge rate of each well is $150 \mathrm{~m}^{3} / \mathrm{hr}$ with maximum daily working hours of 10 . Well spacing is $1 \mathrm{~km}$ to avoid well interaction causing water table depressions, which means that each well covers an area of $1 \mathrm{~km}^{2}$ or about 238 acres. The maximum allowable crop water use is $4000 \mathrm{~m}^{3} /$ acre/year (based on consultation from water and agriculture experts in Egypt) to limit water consumption. Crops such as rice, banana, and alfalfa are prohibited due to high water demands. Modern irrigation technology such as drip and sprinkler should be used [17]. The Ministry of Agriculture and Land Reclamation (MALR) suggested the distribution of lands to be $70 \%$ and $30 \%$ for seasonal and permanent crops, respectively, providing more area for strategic crops [18].

\section{Methodology}

\subsection{Required Crops Area}

One goal of this project is to ensure that local food production is adequate for the population and to sustain livestock farming. While there are 30,000 acres in Siwa for reclamation, it is important to 
determine $A_{v}$. Government policies are followed to identify the number of wells and maximum water available annually, from which $A_{V}$ can be calculated.

This study assumed that the project will commence in 2020 under existing conditions and will not consider potential impacts due to climate change for the next 20 years. To decide if the government goals are achievable by 2040, crops area and total water use for population and livestock were estimated and then compared with the available capacity in Siwa. The first step was to predict the population and corresponding livestock and poultry. ECDC sells land to youth and investors where each land parcel contains a well with a surrounding area of about 238 acres. ECDC sets a condition that each land parcel will be sold to a group of people with a minimum of 10 to a maximum of 23 [19]. As a result, each participant is responsible for at least 10 acres. To estimate the total number of inhabitants at the beginning of the project, assumptions include: each family consists of an average of four members, about 200 personnel are required for community development, and 10 workers are associated with each groundwater well operation. Therefore, the total number of inhabitants in 2020 can be estimated. Future population forecasts will be calculated using an annual growth rate of $2.5 \%$ [2]. Average consumption of beef and poultry is 13 and $10.6 \mathrm{~kg} / \mathrm{capita} /$ year, respectively [20]. While sheep and goats have the great ability to adjust to harsh environmental conditions, they can be raised in arid and semiarid regions [21]. Therefore, due to the dry climate in Siwa, the suggested livestock types are sheep and goats, where both are used to satisfy beef consumption, while chicken is the main source of poultry. Therefore, the total population and livestock can be predicted until 2040.

The second step was to define the area needed for each crop. This study used the land use distribution suggested by MALR, where seasonal crops cover $70 \%$ of the land and consist of wheat, barley, and broad bean in the winter, and maize and soybean in the summer. Permanent crops occupy the remaining $30 \%$ of land with olives and date palm. Wheat, barley, broad bean, and maize are sources of strategic crops to cover the crop deficit in Egypt. Olives, date palm, and soybean are considered cash crops and used as a source of income. Equation (1) is used to calculate the annual area of strategic crops needed for the population:

$$
\text { Crop area }(\text { acres })=\frac{\mathrm{N} * \text { Crop Consumption }(\mathrm{kg} / \text { capita/year })}{1000 * \text { Crop Yield }(\text { ton } / \text { acre })}
$$

where $\mathrm{N}$ is population, and population average consumption for wheat, barley, broad bean, and maize are $143.2,0.3,7.8,62 \mathrm{~kg} / \mathrm{capita} /$ year, respectively [22]. Table 1 shows the average yields of the proposed crops [23].

Table 1. Average yields of crops [23].

\begin{tabular}{|c|c|c|}
\hline \multicolumn{2}{|c|}{ Crop } & \multirow{2}{*}{$\begin{array}{c}\text { Yield (Tons/acre) } \\
2.78\end{array}$} \\
\hline \multirow{2}{*}{ Wheat } & Cereal & \\
\hline & Straw & 2.75 \\
\hline \multirow{2}{*}{ Barley } & Cereal & 1.65 \\
\hline & Straw & 1.83 \\
\hline \multirow{2}{*}{ Broad bean } & Bean & 1.45 \\
\hline & Straw & 1.61 \\
\hline \multirow{2}{*}{ Maize } & Cereal & 3.41 \\
\hline & Stover & 2.54 \\
\hline \multirow{2}{*}{ Soybean } & Bean & 1.4 \\
\hline & Straw & 4.72 \\
\hline \multicolumn{2}{|c|}{ Olives } & 4.15 \\
\hline \multicolumn{2}{|c|}{ Date Palm } & 14.5 \\
\hline
\end{tabular}


Livestock feeds consist of two components: concentrate feeds and roughage feeds. Concentrate feeds correspond to wheat, barley, maize, oats, and broad bean and provide energy and protein for livestock. However, roughage feeds have two types: green fodder that represents alfalfa, sorghum, and silage, and dry fodder which are straws and stover that provide fiber. For sheep and goats, annual feed consumption (Feed ${ }_{\text {sheep }}$ and Feed ${ }_{\text {goat }}$ ) is as follows [24]:

Feed $_{\text {sheep }}=0.6 \mathrm{~kg} /$ day concentrate feed $+0.6 \mathrm{~kg} /$ day dry fodder $+900 \mathrm{~kg} /$ year green fodder

Feed $_{\text {goat }}=0.25 \mathrm{~kg} /$ day concentrate feed $+0.4 \mathrm{~kg} /$ day dry fodder $+600 \mathrm{~kg} /$ year green fodder

In this study, livestock consumption of concentrate feeds will be divided equally among wheat, barley, and broad bean in winter, while maize will be the only source in summer. Straws from wheat, barley, broad bean in addition to stover from maize are the sources of dry fodder. The source of green fodder is silage from maize, which has a yield of 20 tons/acre [25,26]. Thus, areas of wheat, barley, broad bean, and maize as concentrate feeds for livestock are calculated. As a result, the total area of strategic crops needed for the population and livestock can be calculated for 2040. For cash crops, soybean area is assumed to be the area of maize, while olives and date palm are assumed to cover the area of permanent crops equally. Finally, the total crop areas in winter or summer is compared with $\mathrm{A}_{\mathrm{V}}$ to assess land availability.

\subsection{Total Water Use}

To estimate the total water use in 2040, irrigation water, domestic water use, and water requirement for livestock and poultry are identified. Domestic water use is $250 \mathrm{~L} /$ capita/day [27]. The water requirement for sheep and goats is $10 \mathrm{~L} /$ head/day [28], while $0.3 \mathrm{~L} /$ head/day for chicken [29]. For crop water demand, the United Nations Food and Agriculture Organization (FAO) Penman-Monteith equation was used [30], which requires four meteorological data types: maximum temperature, minimum temperature, wind speed, and relative humidity. Monthly data from Siwa in the past 10 years were downloaded from the National Centers for Environmental Prediction (https://globalweather. tamu.edu/). This study used the same steps applied by Moghazy and Kaluarachchi [9] to calculate reference evapotranspiration $\mathrm{ET}_{\mathrm{o}}\left(\mathrm{mm} /\right.$ day) and annual crop evapotranspiration $\mathrm{ET}_{\mathrm{c}}(\mathrm{mm} / \mathrm{year})$ for different crops in Siwa. Equation (4) is used for irrigation water requirement [31]:

$$
\mathrm{IR}=\frac{\mathrm{ET}_{\mathrm{c}}-\mathrm{R}}{(1-\mathrm{LR}) * \mathrm{E}} * 4.2
$$

where IR is crop irrigation requirement ( $\mathrm{m}^{3} /$ acre/year), $\mathrm{R}$ is effective rainfall (mm/year) which is almost negligible in Siwa [15], LR is leaching requirement, 4.2 is a conversion factor from $\mathrm{mm} /$ year to $\mathrm{m}^{3}$ /acre/year, and $\mathrm{E}$ is irrigation efficiency. A drip irrigation system has the distinct advantage over flood and sprinkler irrigation systems in arid regions [32]. Therefore, drip irrigation is assumed to be used in Siwa due to high evaporation, and this assumption is consistent with efficient use of the nonrenewable groundwater resource. The corresponding efficiency is $90 \%$ [33]. The usage of drip irrigation for wheat, barley, and soybean has been supported by earlier experiments [34-38]. Elnashar [39] provided values of LR for different crops in Egypt under different alternatives of irrigation water. Due to the usage of high-quality groundwater from NAS, LR is assumed to be $10 \%$.

Total irrigation water (TIW) of all crops is the sum of IR multiplied by the area of each crop. Therefore, total water use for crops, population, and livestock in 2040 can be estimated and compared with $88 \mathrm{MCM}$, which represents the available annual groundwater from NAS. The value of TIW is divided by $A_{V}$ then compared with $4000 \mathrm{~m}^{3}$ /acre/year to assess the government policy of maximum crop water use. If required crop area and estimated total water use are less than the available capacity of Siwa, then optimization is used to maximize the benefits as presented in the next section. 


\subsection{Optimization Analysis}

Optimization is used in decision-making related to the efficient use of available resources. The common methods of optimization are linear programming (LP), nonlinear programming, dynamic programming, integer programming, binary programming, etc. [40]. LP is one of the best and most simple techniques [41] that helps decision-makers in water resources planning and management. In this work, LP is used to optimize the available capacity of groundwater and land areas by determining the best allocation of crops. The objective function is to maximize crop production by 2040 subject to stipulated government constraints and described as follows:

$$
\operatorname{Max} P=\sum_{i=1}^{n} Y_{i} * A_{i}(i=1,2, \ldots, n)
$$

where $P$ is total crop production (tons), $n$ is number of crops, $Y_{i}$ is yield of crop $i$ (ton/acre) (shown in Table 1$)$, and $A_{i}$ is area of crop $i$ (acres).

As discussed earlier, the constraints can be represented as:

$$
\sum_{i=1}^{\mathrm{w}} \mathrm{A}_{\mathrm{i}} \leq 70 \% \mathrm{~A}_{\mathrm{V}}
$$

where $\mathrm{w}$ is number of seasonal crops in winter, which are wheat, barley, and broad bean.

$$
\sum_{\mathrm{i}=1}^{\mathrm{s}} \mathrm{A}_{\mathrm{i}} \leq 70 \% \mathrm{~A}_{\mathrm{V}}
$$

where $\mathrm{s}$ is number of seasonal crops in summer, which are maize and soybean.

$$
\sum_{i=1}^{m} A_{i} \leq 30 \% A_{V}
$$

where $\mathrm{m}$ is number of permanent crops, which are olives and date palm.

For strategic crop production, the production of each strategic crop should be more than or equal to the total demand by population and livestock.

$$
Y_{j} * A_{j} \geq C P_{j} * N+\sum_{k=1}^{2} C L_{j k} * L_{k}
$$

where $Y_{j}$ is yield of strategic crop $j$ (ton/acre), $j$ is number of strategic crops (wheat, barley, broad bean, and maize), $A_{j}$ is area of strategic crop $\mathrm{j}$ needed for population and livestock (acres), $\mathrm{CP}_{\mathrm{j}}$ is annual consumption of strategic crop $\mathrm{j}$ per capita (ton/capita/year), $\mathrm{k}$ is number of livestock categories (sheep and goats), $\mathrm{CL}_{\mathrm{jk}}$ is consumption of strategic crop $\mathrm{j}$ as concentrate feeds for each $\mathrm{k}$ (ton/head/year), and $\mathrm{L}_{\mathrm{k}}$ is number of heads in each $\mathrm{k}$.

For groundwater availability constraint, the estimated total water use should be less than or equal to available groundwater from NAS, which is $88 \mathrm{MCM} / \mathrm{year}$.

$$
\sum_{\mathrm{i}=1}^{\mathrm{n}}\left(\mathrm{IR}_{\mathrm{i}} * \mathrm{~A}_{\mathrm{i}}\right)+\text { Domestic water use }+ \text { Livestock water requirement } \leq 88 \mathrm{MCM} / \text { year }
$$

where $I_{\mathrm{i}}$ is irrigation requirement for crop i ( $\mathrm{m}^{3} /$ acre/year).

For crop water use constraint, the amount should be less than or equal to the maximum crop water use allowed, which is $4000 \mathrm{~m}^{3} /$ acre/year.

$$
\frac{\sum_{\mathrm{i}=1}^{\mathrm{n}}\left(\mathrm{IR}_{\mathrm{i}} * \mathrm{~A}_{\mathrm{i}}\right)}{\mathrm{A}_{\mathrm{V}}} \leq 4000 \mathrm{~m}^{3} / \text { acre } / \text { year }
$$

The LP model is applied using General Algebraic Modeling Systems (GAMS; http://www.gams.com/). 
Optimization Scenarios

Optimization can be used to analyze possible variations of crop patterns to maximize the production in Siwa. Therefore, this work used scenarios beyond the government policies to explore other agricultural development practices by relaxing some of the government policies. The first scenario was to change land distribution (Equations (6)-(8)) to be $80 \%$ for seasonal crops, while allowing the remaining 20\% for permanent crops and keeping other constraints the same. The purpose of this scenario was to increase the area of strategic crops. The second scenario was to relax only the maximum crop water use (Equation (11)) to determine the increase in crop area and the corresponding crop water use. The third scenario was a combination of the two earlier scenarios.

In the case of extra groundwater needed to expand the agricultural areas, more scenarios will be added to increase water for irrigation by mixing groundwater from NAS with a small volume from PNA that has high salinity. As a result, the corresponding salinity can be calculated using Equations (12) and (13), which depends on the portion of groundwater from each aquifer [42].

$$
\begin{gathered}
E C_{w}=\sum_{i=1}^{g}{E C_{w i} * f_{i}}^{g} \\
\sum_{i=1}^{g} f_{i}=1
\end{gathered}
$$

where $\mathrm{EC}_{\mathrm{w}}$ is electric conductivity after groundwater mix $(\mathrm{ds} / \mathrm{m}), \mathrm{g}$ is number of groundwater resources which are PNA and NAS, $E C_{w i}$ is electric conductivity of groundwater resource $i(d s / m)$, and $f_{i}$ is fraction of source $i$ in the mix. A conversion factor of 650 is used to transfer salinity units from ppm to $\mathrm{ds} / \mathrm{m}$ [43]. To study the effect of groundwater salinity on crop yield, Table 2 is used, which provides tolerance values of crops toward water salinity $[44,45]$.

Table 2. Crop tolerance to water salinity [44,45].

\begin{tabular}{cccccc}
\hline \multirow{2}{*}{ Crop } & $\begin{array}{c}\text { Maximum } \\
\text { Yield }\end{array}$ & $\begin{array}{c}\text { Yield } \\
\text { Reduction by } \\
\mathbf{1 0 \%}\end{array}$ & $\begin{array}{c}\text { Yield } \\
\text { Reduction by } \\
\mathbf{2 5 \%}\end{array}$ & $\begin{array}{c}\text { Yield } \\
\text { Reduction } \\
\text { by } \mathbf{5 0} \%\end{array}$ & $\begin{array}{c}\text { Maximum } \\
\text { Salinity } \\
\text { Possible }\end{array}$ \\
\cline { 2 - 6 } Wheat & 4 & 4.9 & Water Salinity (ds/m) \\
\hline Barley & 5.3 & 6.7 & 8.7 & 8.7 & 13 \\
\hline Broad bean & 1.1 & 1.8 & 2 & 4.5 & 19 \\
\hline Maize & 1.1 & 1.7 & 2.5 & 3.9 & 6.7 \\
\hline Soybean & 3.3 & 3.7 & 4.2 & 5 & 6.7 \\
\hline Olives & 1.8 & 2.6 & 3.7 & 5.6 & 11 \\
\hline Date Palm & 2.7 & 4.5 & 7.3 & 12 & 21 \\
\hline
\end{tabular}

\subsection{Expected Profit}

Previous optimization scenarios described maximizing agricultural production for the proposed project in Siwa without considering profit generated from the project. However, in real-life development projects where investments are made both by the government and private sector, anticipated profit is equally important.

Therefore, annual profit from each scenario can be calculated until 2030 as follows:

$$
\text { Profit }(\$)=\text { Crops Net revenue }- \text { Cost of project }=\left(\sum_{i=1}^{n} S_{i} * Y_{i}-C_{i}\right) * A_{i}-\text { Cost of Project }
$$

where $S_{i}$ is selling price of crop $i\left(\$ /\right.$ ton), and $C_{i}$ is production cost of crop $i$ (\$/acre). 


\subsubsection{Annual Costs}

In this section, all costs of the project in Siwa are identified. This project is still in the first phase of reclamation and has not started yet in Siwa. Therefore, land prices are assumed to be the same as in the first phase, specifically for regions that have similar conditions as Siwa. These land prices are $\$ 2500$ per acre using 2017 dollars for youth, while \$3611 per acre for investors [19]. In this study, an average value of $\$ 3055$ per acre was used in Siwa. The cost of a single deep well is $\$ 194,444$, while the cost of a solar-powered pump is $\$ 72,222$. Costs of irrigation and drainage systems are $\$ 555$ and $\$ 333$ per acre, respectively. Land price includes the price of a well and a solar-powered pump, while maintenance and operation costs, which represent $5 \%$ of the actual cost, is the responsibility of the owner [17]. Capital costs include land price, irrigation, and drainage systems, while annual costs are the costs of maintenance and operation. To convert from capital cost to annual cost, capital recovery factor (CRF) is used as follows (https://en.wikipedia.org/wiki/Capital_recovery_factor accessed November 2019):

$$
\mathrm{CRF}=\frac{\mathrm{r}(1+\mathrm{r})^{\mathrm{U}}}{(1+\mathrm{r})^{\mathrm{U}}-1}
$$

where $r$ is interest rate and $U$ is number of years. All capital costs are assumed to be paid in 10 years with an interest rate of $12.25 \%$ stated by the Central Bank of Egypt (https://www.cbe.org.eg/ar/Pages/ default.aspx accessed February 2020). ECDC sets the policy for cost of land, where $15 \%$ of the cost should be paid in advance when the land is sold, and the remaining $85 \%$ can be paid within nine years with an interest rate of 5\% [19]. As a result, all costs are defined annually.

\subsubsection{Net Revenue}

To calculate net revenue, annual selling prices and production costs are predicted from 2020 to 2030. Cultivated crops such as wheat, barley, broad bean, maize, and soybean have two sell prices; the price of crop and the price of its straw (\$/ton), where yield values are shown in Table 1 . Production costs of these crops include land preparation, seeding and planting, irrigation, fertilization, pest control, harvesting, and labor (\$/acre). However, for date palm, which is a permanent crop, it costs about $\$ 582$ per acre for establishment, which is paid once at the beginning of cultivation and includes land preparation, seeding, and planting costs [46]. The remaining costs such as irrigation, harvesting, and labor are paid annually. The production of dates starts in the fifth year with a yield of $20 \mathrm{~kg} / \mathrm{palm}$ and increases gradually to $125 \mathrm{~kg} / \mathrm{palm}$ in the tenth year [47]. The average number of palms per acre is 115 [23].

The ARIMA model was used in this study to analyze the cost and price data from 2000 to 2017 for all crops, in addition to developing appropriate models that can predict these values for the next 10 years with a confidence level of $95 \%$ for prediction interval. As a result, net revenues can be calculated. The ARIMA (p, d, q) model is a combination of three parts: Autoregressive AR(p), Integrated $\mathrm{I}(\mathrm{d})$, and Moving Average MA(q). $\mathrm{AR}(\mathrm{p})$ refers to the use of past values in the regression equation. $\mathrm{I}(\mathrm{d})$ is the differencing between observations to achieve the stationary assumption where there is no trend or seasonality in the data. MA(q) represents the error of the model as a combination of previous errors. The equation of the ARIMA model is as follows:

$$
\mathrm{Y}_{\mathrm{t}}=\mathrm{c}+\varphi_{1} \mathrm{y}_{\mathrm{d} t-1}+\ldots+\varphi_{\mathrm{p}} \mathrm{y}_{\mathrm{d} t-\mathrm{p}}+\mathrm{e}_{\mathrm{t}}-\theta_{1} \mathrm{e}_{\mathrm{t}-1}-\theta_{\mathrm{q}} \mathrm{e}_{\mathrm{t}-\mathrm{q}}
$$

where $Y_{t}$ is variable at time $t, c$ is constant, $\varphi_{1}, \varphi_{p}, \theta_{1}$, and $\theta_{q}$ are parameters from the model, $d$ is degree of differencing, $p$ is number of lag observations, $q$ is size of moving average window, and $e_{t}$ is error at time $t$.

Autocorrelation function (ACF) and Partial autocorrelation function (PACF) are used to estimate the characteristics of time series. ACF plots display the correlation between a series and its lags, which can help to estimate the order of MA(q). However, PACF plots display the direct relationship between 
a variable and its lag, so the order of $\mathrm{AR}(\mathrm{p})$ can be estimated. Annual historical data about the prices and costs of cultivated crops are collected from the Ministry of Agriculture and Land Reclamation [48] and the Central Agency for Public Mobilization and Statistics [49]. Data are divided into two sets: training set from 2000 to 2010, and test set for the remaining seven years' data from 2011 to 2017. These steps can help to test the accuracy of the ARIMA model for future predictions of prices and costs for each crop.

The selection of the ARIMA model that fitted the training set is based on goodness-of-fit criteria. In this work, we used mean absolute error (MAE), root-mean-squared error (RMSE), and mean absolute percentage error (MAPE). Models that have lower values of MAE, RMSE, and MAPE are used to predict data from 2011 to 2017, then compared with the test set to measure the performance of forecasting. As a result, production cost and sell price of each crop can be predicted with a confidence level of $95 \%$ for prediction intervals. MAE, RMSE, and MAPE are defined as follows:

$$
\begin{gathered}
\text { MAE }=\frac{1}{U} \sum_{i=1}^{U}\left(Y_{i}-\hat{Y}_{i}\right) \\
\text { RMSE }=\sqrt{\frac{1}{U} \sum_{i=1}^{U}\left(Y_{i}-\hat{Y}_{i}\right)^{2}} \\
\text { MAPE }=\frac{100}{U} \sum_{i=1}^{U}\left|\frac{Y_{i}-\hat{Y}_{i}}{Y_{i}}\right|
\end{gathered}
$$

where $Y_{i}$ and $\hat{Y}_{i}$ represent observed and predicted values in year $i$, respectively. The ARIMA model was applied using R software version 3.6.1 (https://www.r-project.org/). Finally, revenues from the cultivated crops are predicted annually from 2020 to 2030. As a result, profit is estimated for each scenario using Equation (14).

\subsection{Profit Uncertainty}

In the previous section, selling prices and production costs of crops have uncertainty in the prediction intervals. Therefore, this uncertainty in profit is addressed using Monte Carlo simulations (MCS), which require the probability distribution of input variables to describe uncertainty. A common approach in financial forecasting is the triangular distribution, where the minimum, maximum, and most likely value are known to occur [50,51]. Therefore, this work used triangular distribution for predicted prices and costs of crops in years 2025 and 2030. The number of simulations used was 10,000 to increase the accuracy, as suggested by [52]. R software is also used for the Monte Carlo simulations.

\section{Results and Discussion}

\section{1. $A_{v}$}

Government policies are followed to ensure the sustainability of NSAS for future generations. Each well covers an area of 238 acres, which indicates that 126 wells are needed to cultivate 30,000 acres. Using stipulated well discharge rate and working hours, the maximum water available annually is $68 \mathrm{MCM}$. By dividing this value by maximum crop water use of $4000 \mathrm{~m}^{3} / \mathrm{acre}, \mathrm{A}_{\mathrm{v}}$ is computed as 17,010 acres, which represents $56.7 \%$ of the total area. As a result, each well can cultivate only 135 acres. The remaining areas can be used for stocks, fishing, and livestock farming. Using the land distribution of 30\% for permanent crops and 70\% for seasonal crops, there are 5103 acres available for olives and date palm, while 11,907 acres are available for wheat, barley, and broad bean in winter, and maize, and soybean in the summer.

\subsection{Crop Area and Total Water Use in 2040}

The purpose of this section is to assess if government goals are achievable by 2040 where crop area and total water use for population and livestock are estimated and then compared with available 
capacity in Siwa. It is mentioned earlier that each participant is responsible for at least 10 acres; therefore, 30,000 acres in Siwa can be sold to approximately 3000 persons. Using the assumptions made earlier, the number of inhabitants at the beginning of the project is 16,460 in 2020 . The predicted population in 2040 will be 26,972 using an annual population growth rate of $2.5 \%$. The corresponding estimated numbers of sheep, goats, and chickens in 2040 are 5127, 7969, and 204,987, respectively.

To calculate the area of strategic crops for population needs, Equation (1) is used. For livestock feeds, Equations (2) and (3) are used where the total values of concentrate feeds, dry, and green fodders needed in 2040 are 1850, 2287, and 9396 tons, respectively. As wheat, barley, broad bean, and maize are the sources for concentrate feeds, Table 3 shows the details to compute these areas. Thereafter, the total area of strategic crops needed for population and livestock concentrate feeds in 2040 are 1501, 192, 358, and 763 acres for wheat, barley, broad bean, and maize, respectively, as shown in Table 4 . It is important to ensure that these areas are enough to meet dry and green fodders for livestock. Dry fodder required in winter or summer is 1143.5 tons. The production of wheat straw is 4127 tons, which can cover the consumption of dry fodder in winter. The production of maize stover is 1938 tons, which is enough to cover dry fodder in summer. For green fodder, the production of silage from maize is 15,260 tons, where this quantity is enough for the whole year. For cash crops, areas of soybean, olives, and date palms are 763, 2551, and 2552, respectively, based on the assumptions made earlier. As a result, the total area required in winter is 7154 acres, which is the summation of land needs of wheat, barley, broad bean, olives, and date palm. Less area is needed in the summer, which is about 6629 acres. The comparison between crop areas required in winter or summer with $A_{v}$ of 17,010 acres indicates that there is still extra area available that can be cultivated in Siwa.

Table 3. Strategic crops area for livestock concentrate feeds in 2040.

\begin{tabular}{ccccc}
\hline & Consumption per Season & Crop & Consumption per Crop (tons) & Area (acres) \\
\hline \multirow{2}{*}{$\begin{array}{c}\text { Concentrate feeds } \\
=1850 \text { tons/year }\end{array}$} & \multirow{2}{*}{ Winter $=925$ tons } & Wheat & 308.3 & 111 \\
\cline { 2 - 4 } & & Barley & 308.3 & 187 \\
\cline { 2 - 5 } & & Broad bean & 308.3 & 213 \\
\cline { 2 - 5 } & Summer $=925$ tons & Maize & 925 & 272 \\
\hline
\end{tabular}

Table 4. Calculated required areas (in acres) for strategic crops in 2040.

\begin{tabular}{cccc}
\hline Crop & Area for Population Needs & Area for Livestock Needs & Total Area \\
\hline Wheat & 1390 & 111 & 1501 \\
\hline Barley & 5 & 187 & 192 \\
\hline Broad bean & 145 & 213 & 358 \\
\hline Maize & 491 & 272 & 763 \\
\hline
\end{tabular}

Domestic water use, in addition to water requirements for livestock and poultry, are $2.5 \mathrm{MCM}$ in 2040. Irrigation requirement for each crop is calculated using Equation (4) and the results are shown in Table 5. As a result, TIW for all crops is $38.1 \mathrm{MCM}$ in 2040, and the corresponding total water use is $40.6 \mathrm{MCM}$, which is less than $88 \mathrm{MCM}$. When TIW is divided by 17,010 , crop water use is about $2240 \mathrm{~m}^{3}$ /acre/year, which is less than $4000 \mathrm{~m}^{3} /$ acre/year. These results indicate that government goals are achievable in 2040 where the available land and groundwater are adequate for the estimated population needs while allowing further expansion of agriculture. 
Table 5. Calculated crop irrigation requirement (IR).

\begin{tabular}{cc}
\hline Crop & $\begin{array}{c}\text { IR } \\
\left(\mathbf{m}^{3} \text { /acre/year }\right)\end{array}$ \\
\hline Wheat & 2504 \\
\hline Barley & 2281 \\
\hline Broad bean & 2184 \\
\hline Maize & 4046 \\
\hline Soybean & 3750 \\
\hline Olives & 4198 \\
\hline Date palm & 6449 \\
\hline
\end{tabular}

\subsection{Optimization}

Since the earlier analysis showed that more capacity is available in the system, optimization is used to evaluate possible scenarios to increase production. Table 6 shows the results of LP optimization for all scenarios discussed earlier. It is clear that, in all scenarios, soybean and olives are not appropriate due to their lower yields compared to maize and date palm, respectively. For seasonal crops, the production of barley and broad bean satisfies only the required values for population and livestock, while extra areas can be cultivated with wheat in the winter and maize in the summer. Date palm is the only source of income and can always cover the entire area allocated to permanent crops.

For the base scenario where government policies are followed, the production of wheat and maize are 31,572.5 and 4619.5 tons, respectively, indicating that production exceeds demand. Therefore, extra production can be used outside Siwa to cover the national deficit of strategic crops in Egypt. Total crop production, which is the objective function, is 111,021 tons, while the total production of strategic crops is 37,027 tons. For the first scenario where the land distribution changed to $80 \%$ for strategic crops and $20 \%$ for permanent crops, the results show that production of wheat and maize increased by $15 \%$ and $122.4 \%$, respectively, compared with the base scenario. However, total production decreased by about $12.8 \%$ because of the decrease in date palm area by $33.3 \%$. In the base case and first scenarios, there is still available groundwater and land in the summer, but this land could not be cultivated due to the constraint of crop water use.

In the second scenario where maximum crop water use is relaxed, the only change is in the production of maize, which increases by about $318.6 \%$ compared with the base scenario. Thereafter, the total production increased by about $13.3 \%$. For the third scenario, which is the combination of the first and second scenarios, the results show that the production of wheat and maize increased about $15 \%$ and $441 \%$, respectively, while total production did not change much compared with the base scenario. In the second and third scenarios, crop water use is $5026 \mathrm{~m}^{3} /$ acre/year and all available groundwater in NAS is needed. Therefore, to withdraw $88 \mathrm{MCM}$, the discharge rate from each well needs to increase to about $194 \mathrm{~m}^{3} / \mathrm{hr}$ instead of $150 \mathrm{~m}^{3} / \mathrm{hr}$, or increase the number of wells to 163 instead of 126. There is still an available area in the summer that can be cultivated, but the constraint of groundwater availability is violated.

The comparison between these scenarios shows that the whole area of 17,010 acres can be cultivated in the winter but not in the summer, due to the higher crop water demand. It is recommended that decision-makers should consider increasing the limit of crop water use, in addition to increasing the discharge rate of wells and the number of wells where possible. 
Table 6. Results from optimization analysis for different scenarios.

\begin{tabular}{|c|c|c|c|c|c|c|c|c|}
\hline \multirow{2}{*}{ Crop } & \multirow{2}{*}{\multicolumn{2}{|c|}{ Population and Livestock Requirement }} & \multicolumn{6}{|c|}{ Scenarios to Maximize Production } \\
\hline & & & Base Scenario & Scenario 1 & Scenario 2 & Scenario 3 & Scenario 4 & Scenario 5 \\
\hline \multirow{2}{*}{ Wheat } & Area (acres) & 1501 & 11,357 & 13,058 & 11,357 & 13,058 & $11,318.7$ & $13,019.7$ \\
\hline & Production (tons) & 4172.8 & $31,572.5$ & $36,301.2$ & $31,572.5$ & $36,301.2$ & 31,466 & $36,194.8$ \\
\hline \multirow{2}{*}{ Barley } & Area (acres) & 192 & 192 & 192 & 192 & 192 & 192 & 192 \\
\hline & Production (tons) & 316.8 & 316.8 & 316.8 & 316.8 & 316.8 & 316.8 & 316.8 \\
\hline \multirow{2}{*}{ Broad bean } & Area (acres) & 358 & 358 & 358 & 358 & 358 & 396.3 & 396.3 \\
\hline & Production (tons) & 519.1 & 519.1 & 519.1 & 519.1 & 519.1 & 519.1 & 519.1 \\
\hline \multirow{2}{*}{ Maize } & Area (acres) & 763 & 1354.7 & 3013.2 & 5670.5 & 7328.9 & 10,617 & $12,275.5$ \\
\hline & Production (tons) & 2601.8 & 4619.5 & 10,275 & $19,336.4$ & $24,991.5$ & 31,851 & $36,826.5$ \\
\hline \multirow{2}{*}{ Date palm } & \multicolumn{2}{|c|}{ Area (acres) } & 5103 & 3402 & 5103 & 3402 & 5103 & 3402 \\
\hline & \multicolumn{2}{|c|}{ Production (tons) } & $73,993.5$ & 49,329 & $73,993.5$ & 49,329 & $73,993.5$ & 49,329 \\
\hline \multicolumn{3}{|c|}{ Total area in Winter (acres) } & 17,010 & 17,010 & 17,010 & 17,010 & 17,010 & 17,010 \\
\hline \multicolumn{3}{|c|}{ Total area in Summer (acres) } & 6457.7 & 6415.2 & $10,773.5$ & $10,730.9$ & 15,720 & $15,677.5$ \\
\hline \multicolumn{3}{|c|}{ Crop water use ( $\mathrm{m}^{3} /$ acre/year) } & 4000 & 4000 & 5026.5 & 5026.5 & 6202.2 & 6202.2 \\
\hline \multicolumn{3}{|c|}{ Total water use (MCM/year) } & 70.5 & 70.5 & 88 & 88 & 108 & 108 \\
\hline \multicolumn{3}{|c|}{ Objective function (tons) } & $111,021.4$ & $96,741.2$ & $125,738.3$ & $111,457.7$ & $138,146.4$ & $123,186.2$ \\
\hline \multicolumn{3}{|c|}{ Strategic crop production (tons) } & $37,027.9$ & $47,412.2$ & $51,744.8$ & $62,128.7$ & $64,152.9$ & $73,857.2$ \\
\hline
\end{tabular}


Another solution is to increase the irrigation water supply by mixing PNA with NAS, considering the effect of water salinity on crop yield. Average values of groundwater salinity are $5000(7.7 \mathrm{ds} / \mathrm{m})$ and $300 \mathrm{ppm}(0.46 \mathrm{ds} / \mathrm{m})$ for PNA and NAS, respectively. Domestic water use of $2.5 \mathrm{MCM}$ in $2040 \mathrm{can}$ use high-quality groundwater from NAS. However, the remaining amount of $85.5 \mathrm{MCM}$ from NAS can be mixed with $20 \mathrm{MCM}$ from PNA. The corresponding salinity from this mix using Equations (12) and (13) is $1.83 \mathrm{ds} / \mathrm{m}$. From Table 2, the only crops that will be affected by groundwater salinity are broad bean and maize, where the decrease in yield is $10 \%$ and $12 \%$, respectively. As a result, yield values of broad bean and maize can decrease to 1.31 and 3 ton/acre, respectively.

Scenarios 4 and 5 have the same conditions as 2 and 3, respectively, but with more groundwater available at $108 \mathrm{MCM}$. The results show that, although the yield of maize decreased by $12 \%$ in scenarios 4 and 5 , the production of maize increased by $64.7 \%$ and $47.4 \%$ compared with scenarios 2 and 3, respectively. In addition, cultivated areas in the summer increased to cover about $92 \%$ of $A_{v}$. The comparison between all scenarios shows that scenario 4 has the maximum production of 138,146 tons from all crops. When maximizing production of strategic crops only is considered, scenario 5 is recommended, which produces 73,857 tons. With either of these two scenarios, policy-makers may have to decide to increase the limit of crop water use to $6202 \mathrm{~m}^{3} /$ acre/year, in addition to increase well discharge rate and the number of wells to withdraw $88 \mathrm{MCM}$ from NAS, while for PNA, policy-makers can define a suitable discharge rate and working hours to withdraw $20 \mathrm{MCM}$.

\subsection{Profits}

To estimate profit until 2030, costs of the proposed project and revenues from crops are calculated annually. As mentioned earlier, costs of the project include capital and annual costs. Table 7 summarizes these costs, where CRF is used to convert from capital cost to annul cost.

Table 7. Annual cost data.

\begin{tabular}{cc}
\hline Type of Cost & Description \\
\hline $15 \%$ of land price $(\$)$ & Paid once at the beginning of the project \\
\hline $85 \%$ of land price (\$/year) & $\begin{array}{c}\text { Capital cost is paid annually with an interest rate of } \\
5 \% \text { for a life span of } 9 \text { years }(\mathrm{CRF}=0.141)\end{array}$ \\
\hline Cost of irrigation system (\$/year) & $\begin{array}{c}\text { Capital cost is paid annually with an interest rate of } \\
12.25 \% \text { for a life span of } 10 \text { years }(\mathrm{CRF}=0.178)\end{array}$ \\
\hline Cost of drainage system (\$/year) & $\begin{array}{c}\text { Capital cost is paid annually with an interest rate of } \\
12.25 \% \text { for a life span of } 10 \text { years }(\mathrm{CRF}=0.178)\end{array}$ \\
\hline Maintenance of wells (\$/year) & Paid annually for 126 wells \\
\hline Maintenance of solar pumps (\$/year) & Paid annually for 126 pumps \\
\hline Maintenance of irrigation and drainage systems $(\$ /$ year) & Paid annually \\
\hline
\end{tabular}

Optimization results show that wheat, barley, broad bean, maize, and date palm are the only required crops. Therefore, the ARIMA model is applied to predict the annual sell prices and production costs of all crops from 2020 to 2030, such that net revenues can be estimated. Steps to choose the best ARIMA model to predict the price of wheat cereal are presented in this study. Figure 3 shows the time series for annual price of wheat from 2000 to 2010, which is the training set. The analysis indicates an increasing trend in prices, such that differencing is applied to time-series data to make it stationary. Figure 4 shows the plots of ACF and PACF that are used to estimate initial values of $A R(p)$ and MA(q). This plot indicates that there is only one significant spike in ACF and the same for PACF. As a result, different ARIMA models are suggested and goodness-of-fit criteria are used to find better models that fit the training set as shown in Table 8 . 


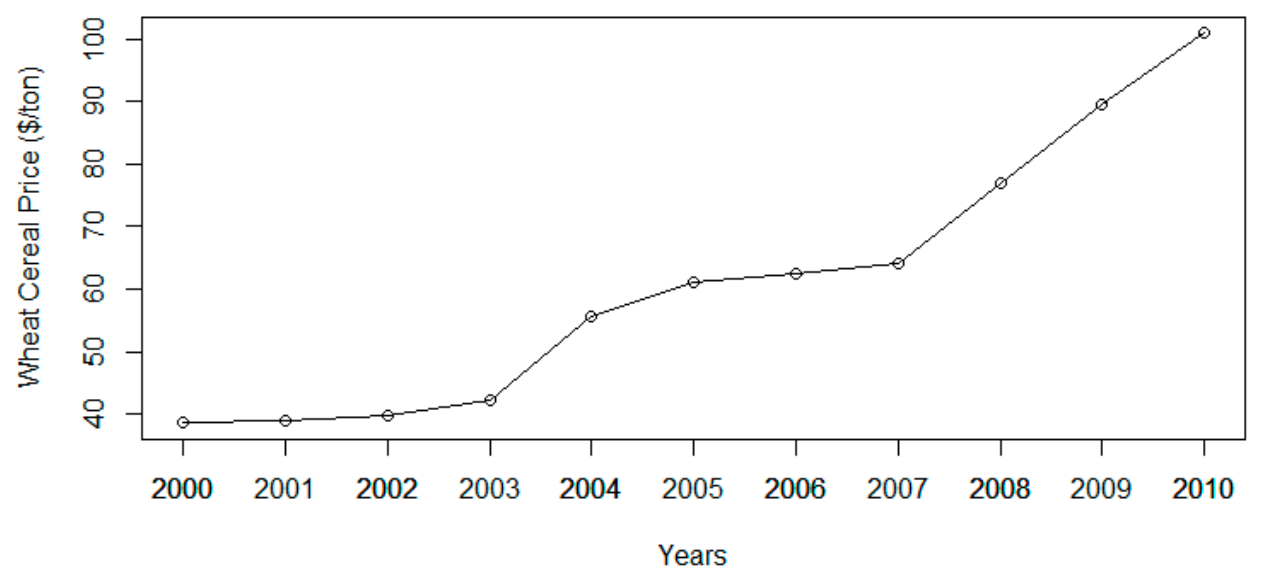

Figure 3. Time-series plot of annual price of wheat cereal from 2000 to 2010.

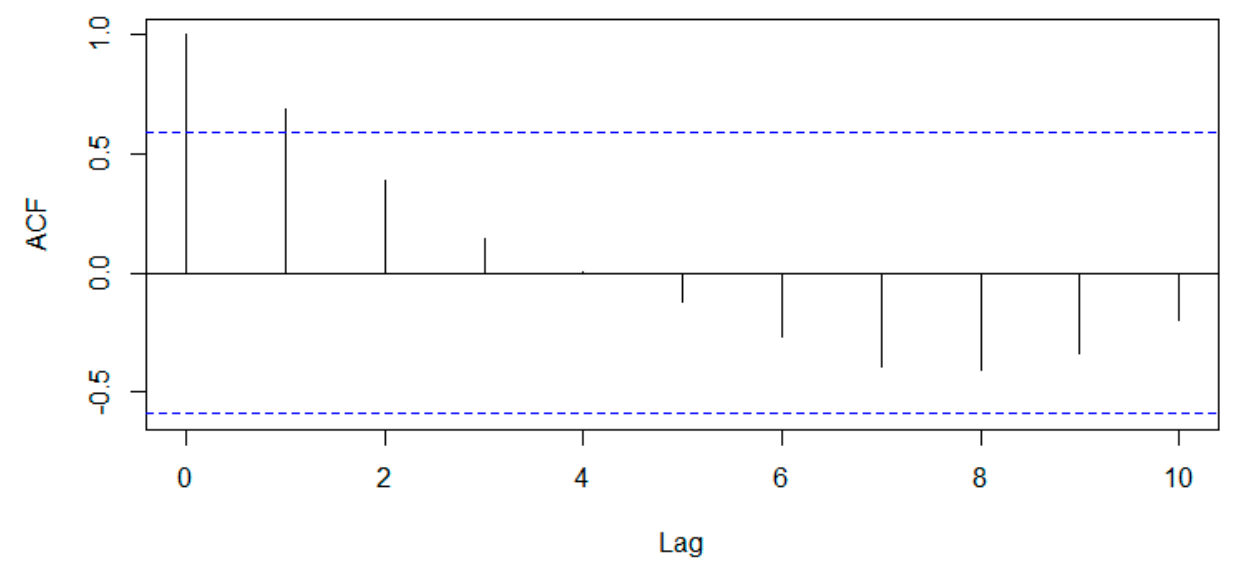

(a)

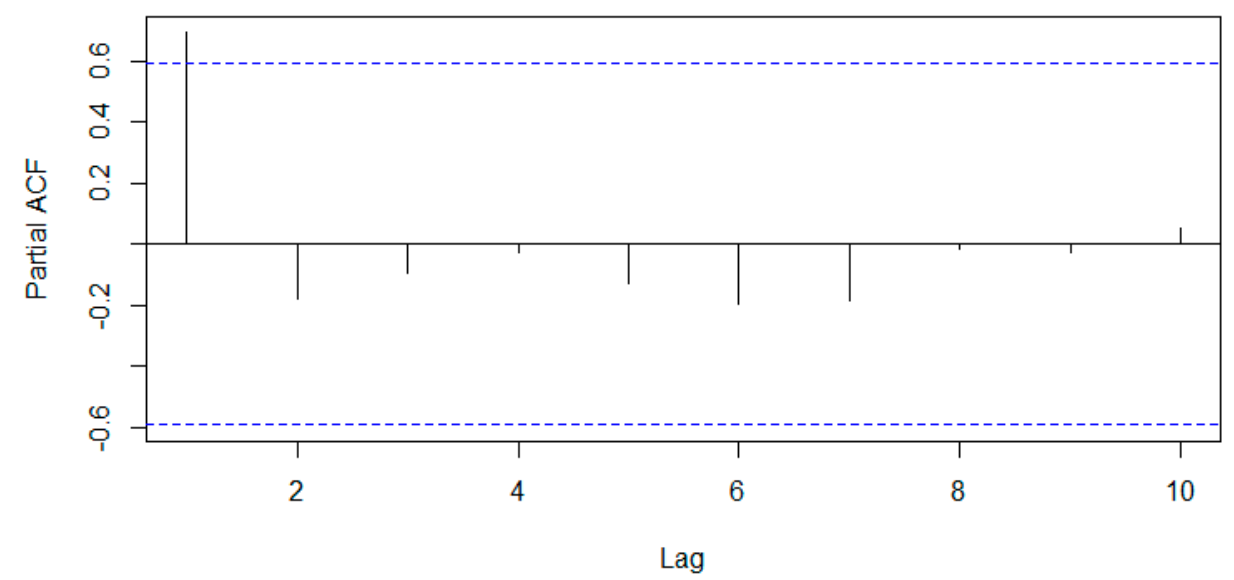

(b)

Figure 4. Plots for the price of wheat cereal; (a) ACF and (b) PACF.

The results show that ARIMA $(2,2,2)$ and $(2,3,2)$ have the lower error values and are chosen to predict the prices of wheat cereal through 2011 to 2017 with $95 \%$ confidence level for prediction intervals. To identify the accuracy of these two models, the predicted data were compared with test sets using MAE, RMSE, and MAPE. The results show that values of MAE, RMSE, and MAPE for ARIMA $(2,2,2)$ are 17.7, 21.5, and 11.3, respectively, while for ARIMA $(2,3,2)$ these values are 13.4, 16.7, 
and 9.1, respectively. As a result, ARIMA $(2,3,2)$ was selected to predict the price of wheat cereal with perdition intervals at $95 \%$ confidence level as shown in Figure 5 . These steps are repeated to predict prices and production costs for all cultivated crops until 2030 and the corresponding ARIMA models are shown in Table 9. As a result, net revenues from these crops can be calculated.

Table 8. Goodness-of-fit criteria of ARIMA models for the price of wheat cereal.

\begin{tabular}{cccccc}
\hline ARIMA & $\mathbf{( 2 , 1 , 1 )}$ & $\mathbf{( 2 , 2 , 2 )}$ & $\mathbf{( 1 , 2 , 2 )}$ & $\mathbf{( 1 , 3 , 3 )}$ & $\mathbf{( 2 , 3 , 2 )}$ \\
\hline MAE & 3.5 & 2.13 & 3.3 & 2.8 & 2.53 \\
\hline RMSE & 5.37 & 3.32 & 5 & 4.2 & 3.68 \\
\hline MAPE & 5.4 & 3.3 & 5.13 & 4.44 & 3.93 \\
\hline
\end{tabular}

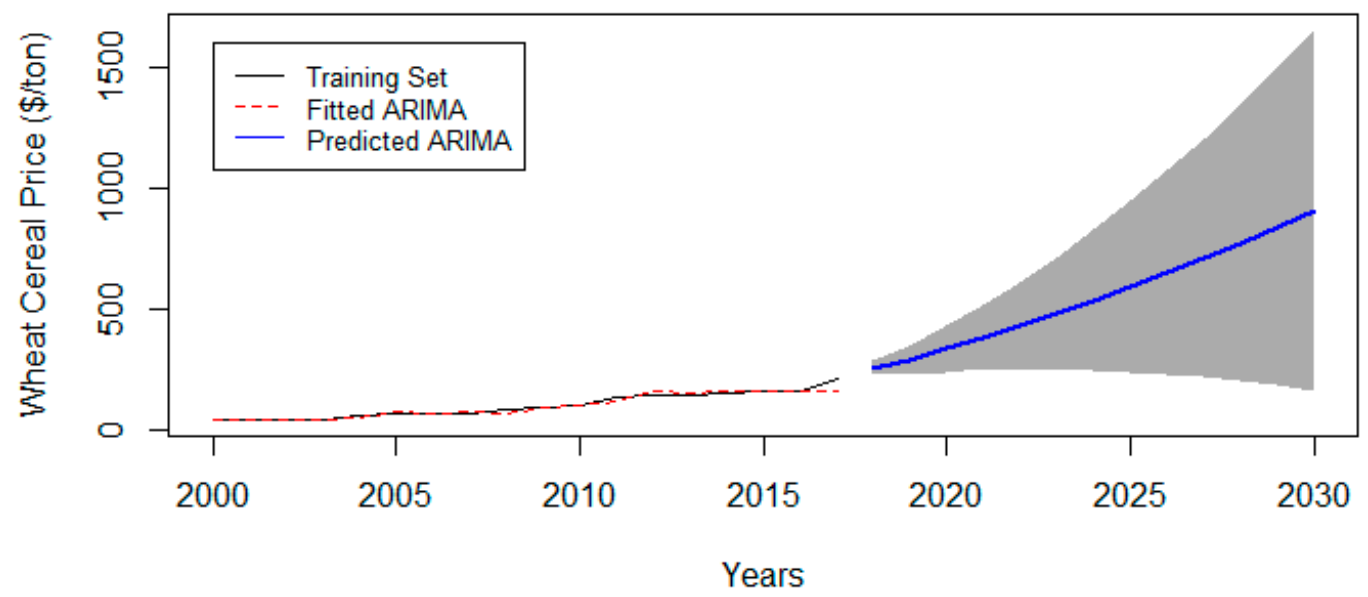

Figure 5. Predicted values using ARIMA $(2,3,2)$. Note that shaded areas represent perdition intervals with a $95 \%$ confidence level.

Table 9. Results of ARIMA model for all crops.

\begin{tabular}{|c|c|c|}
\hline & Crop & ARIMA \\
\hline \multirow{3}{*}{ Wheat } & Cereal price & $(2,3,2)$ \\
\hline & Straw price & $(2,2,2)$ \\
\hline & Production cost & $(2,3,2)$ \\
\hline \multirow{3}{*}{ Barley } & Cereal price & $(1,3,3)$ \\
\hline & Straw price & $(3,3,2)$ \\
\hline & Production cost & $(0,2,2)$ \\
\hline \multirow{3}{*}{ Broad bean } & Bean price & $(2,2,1)$ \\
\hline & Straw price & $(0,2,2)$ \\
\hline & Production cost & $(1,2,1)$ \\
\hline \multirow{3}{*}{ Maize } & Cereal price & $(1,2,3)$ \\
\hline & Straw price & $(2,2,2)$ \\
\hline & Production cost & $(2,2,1)$ \\
\hline \multirow{2}{*}{ Date Palm } & Price & $(2,2,2)$ \\
\hline & Annual cost & $(2,3,1)$ \\
\hline
\end{tabular}

Table 10 shows profits from each scenario from 2020 to 2030. Negative values of profit are present at the beginning of the project because of date palm, where the production of this cash crop starts in year 5 . 
Table 10. Estimated profit for each scenario.

\begin{tabular}{cccccccccccc}
\hline Profits (\$ million) & $\mathbf{2 0 2 0}$ & $\mathbf{2 0 2 1}$ & $\mathbf{2 0 2 2}$ & $\mathbf{2 0 2 3}$ & $\mathbf{2 0 2 4}$ & $\mathbf{2 0 2 5}$ & $\mathbf{2 0 2 6}$ & $\mathbf{2 0 2 7}$ & $\mathbf{2 0 2 8}$ & $\mathbf{2 0 2 9}$ & $\mathbf{2 0 3 0}$ \\
\hline Base Scenario & -29.8 & -12.4 & -12 & -11.4 & 22.3 & 40.6 & 59.7 & 97.5 & 136.8 & 188.8 & 243.6 \\
\hline Scenario 1 & -25.2 & -8.3 & -7.5 & -6.4 & 16.8 & 29.7 & 43.2 & 69.2 & 96.2 & 135.4 & 173.8 \\
\hline Scenario 2 & -28.3 & -10.9 & -10.4 & -9.7 & 24.1 & 42.4 & 61.6 & 99.5 & 138.9 & 190.9 & 245.9 \\
\hline Scenario 3 & -23.6 & -6.7 & -5.8 & -4.7 & 18.6 & 31.6 & 45.2 & 71.2 & 98.3 & 137.5 & 176.0 \\
\hline Scenario 4 & -27.4 & -10.0 & -9.5 & -8.8 & 25.1 & 43.4 & 62.7 & 100.5 & 140.0 & 192.1 & 247.0 \\
\hline Scenario 5 & -22.9 & -6.0 & -5.0 & -3.9 & 19.4 & 32.4 & 46.1 & 72.1 & 99.2 & 138.5 & 177.0 \\
\hline
\end{tabular}

Figure 6 shows a comparison between the base scenario and the five scenarios in crop production and cumulative profits from 2020 to 2030 .

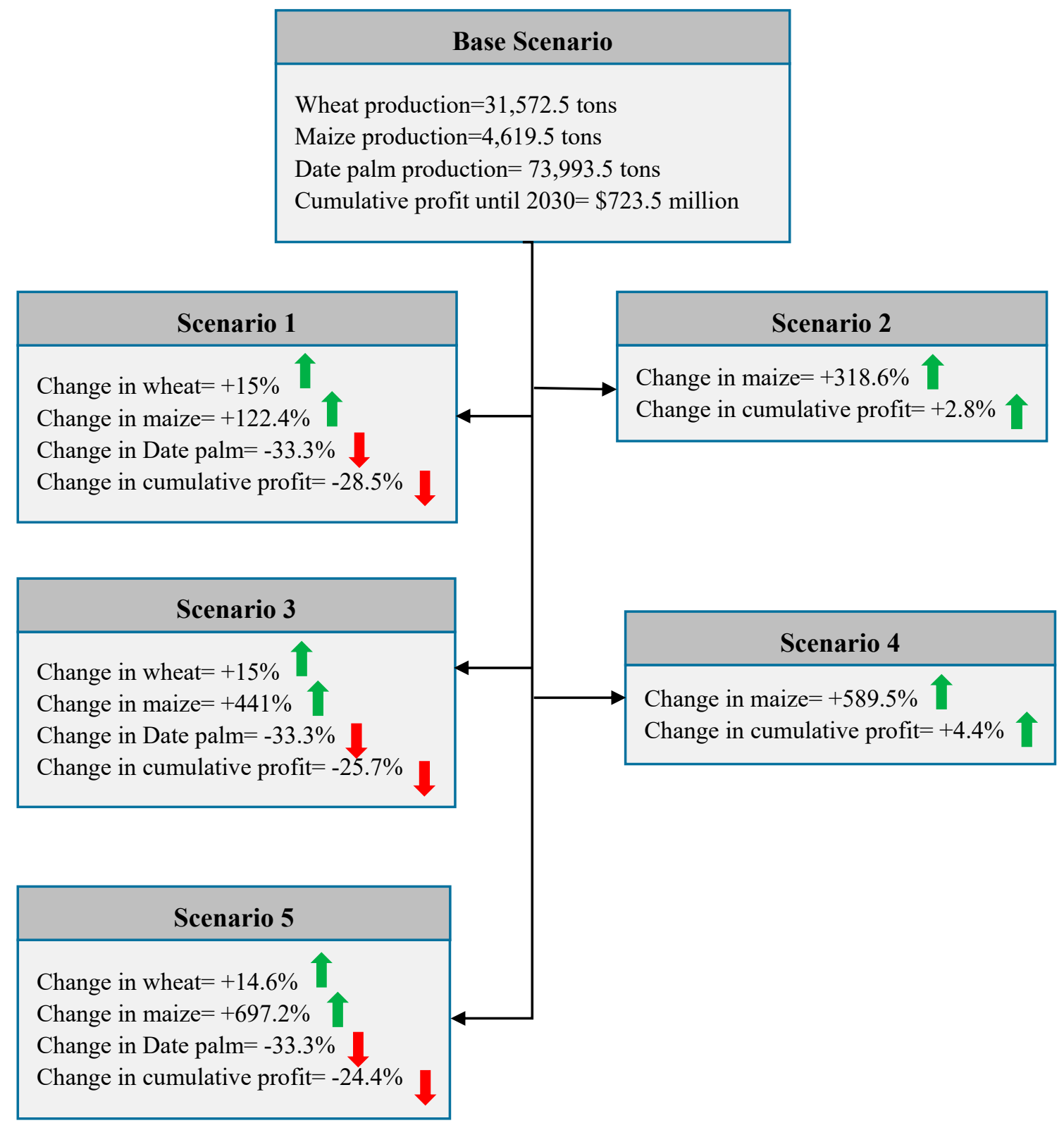

Figure 6. Comparison between scenarios for crop production and profit.

This plot indicates that the cumulative profits in scenarios 1, 3, and 5 decreased by $28.5 \%, 25.7 \%$, and $24.4 \%$, respectively, compared to the base scenario because of the decrease in date palm area, 
which is the source of income; however, there is an extra production in strategic crops. For instance, in scenario 5, extra production of wheat and maize can feed around 33,000 and 519,467 people, respectively. For scenarios 2 and 4 , there is an increase in cumulative profits of about $2.8 \%$ and $4.4 \%$, respectively, compared with the base scenario, as date palm area covers the entire $30 \%$ area of permanent crops. Scenario 4 has more profit than scenario 2 because of more groundwater availability. As a result, the highest cumulative profit is $\$ 755.2$ million in scenario 4 given the maximum production, while scenario 1 has the lowest value of $\$ 517$ million.

\subsection{Uncertainty Analysis}

Due to the uncertainty and risks in estimating future profit, Monte Carlo simulations (MCS) were applied in years 2025 and 2030. The probability distributions of prices and production costs of cultivated crops are triangular distributions, and the number of simulations is 10,000 . Figure 7 shows box plots of profit from all scenarios for 2025 and 2030. The comparison between all scenarios shows that the median of profit for the base scenario, and scenarios 2 and 4, are around $\$ 42$ million and $\$ 245$ million in 2025 and 2030, respectively. However, for the remaining scenarios, these values are $\$ 31$ million and \$175 million in 2025 and 2030, respectively. These values are close to the estimated profit shown in Table 10. The higher profits are present in the base scenario, and scenarios 2 and 4, because the land distribution allocated $30 \%$ for cash crops.

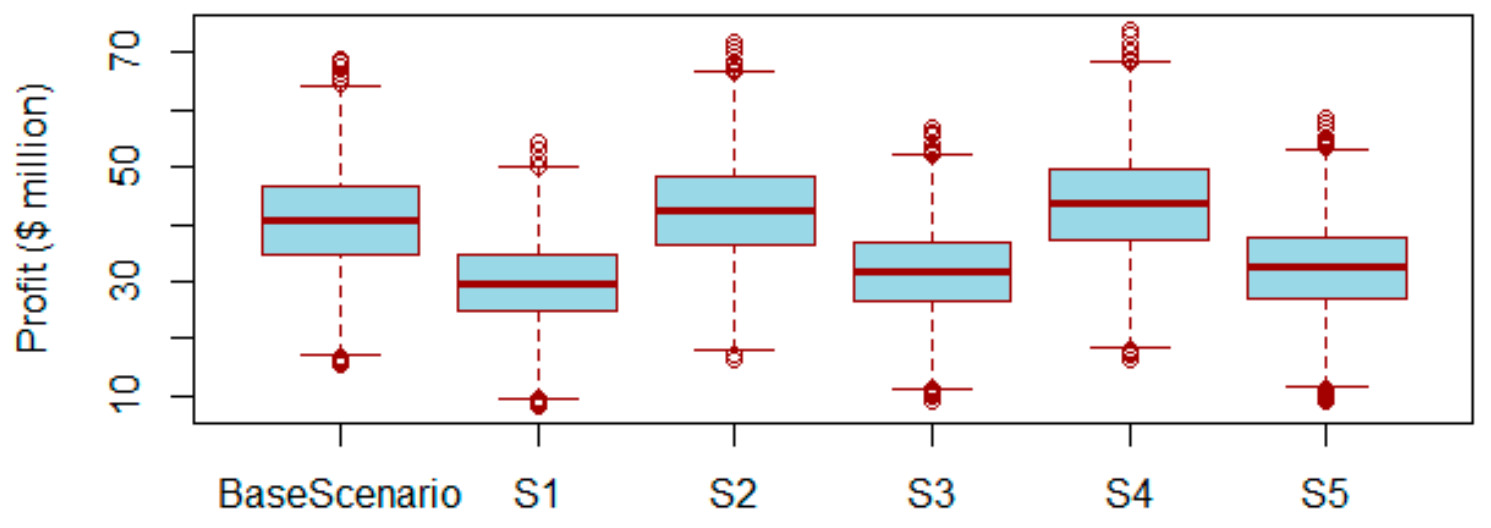

\section{Scenarios}

(a)

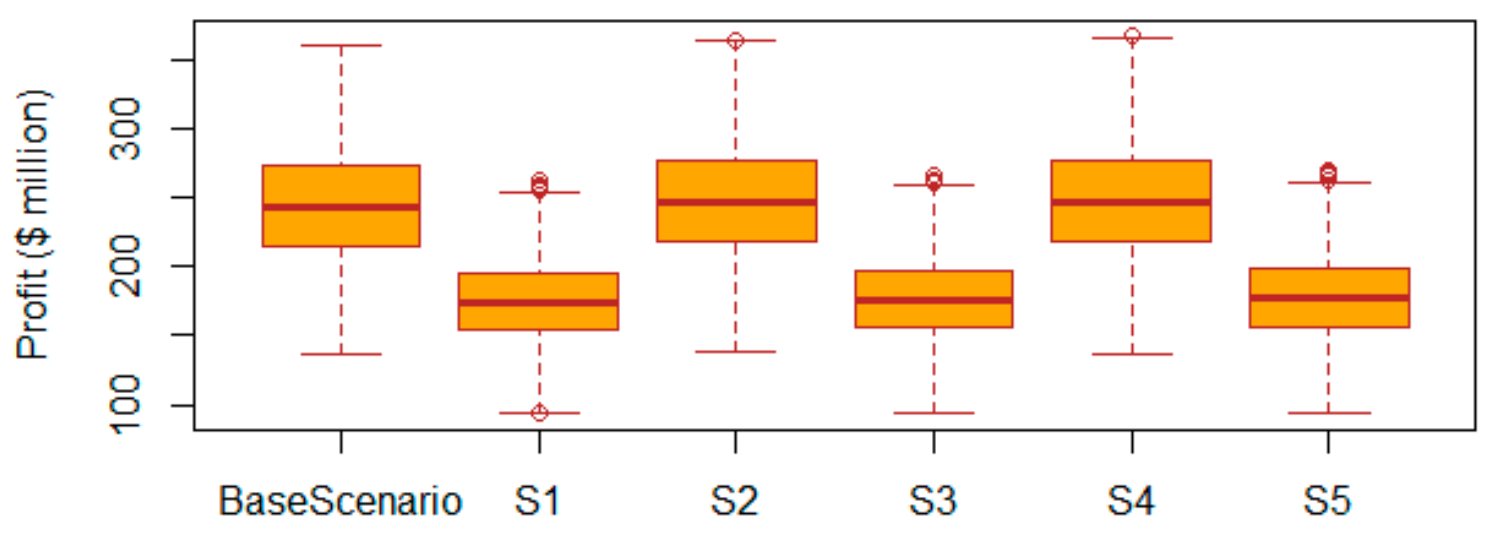

Scenarios

(b)

Figure 7. Box plot of profit from uncertainty analysis for all scenarios: (a) 2025 and (b) 2030 . 
To evaluate the risk to profit, histograms are used and shown for the base scenario and scenario 5. These two scenarios are chosen as these represent two situations where the base scenario follows the government policy, while scenario 5 allows advancing beyond these policies to increase crops production. Figure 8 shows the cumulative probability distribution of profits for the base scenario in years 2025 and 2030. The results indicate that there is $95 \%$ probability that profits can be $\$ 56.9$ million and \$323.3 million in 2025 and 2030, respectively. However, the profits for scenario 5 at same probability can be $\$ 47.4$ million and $\$ 239.5$ million in 2025 and 2030, respectively, as shown in Figure 8 . Comparing these values with Table 10 shows that expected profits with uncertainty considered can exceed the estimated values by about $1.3 \%$. As a result, there is a low risk of not achieving the estimated profit subjected to the conditions selected here.

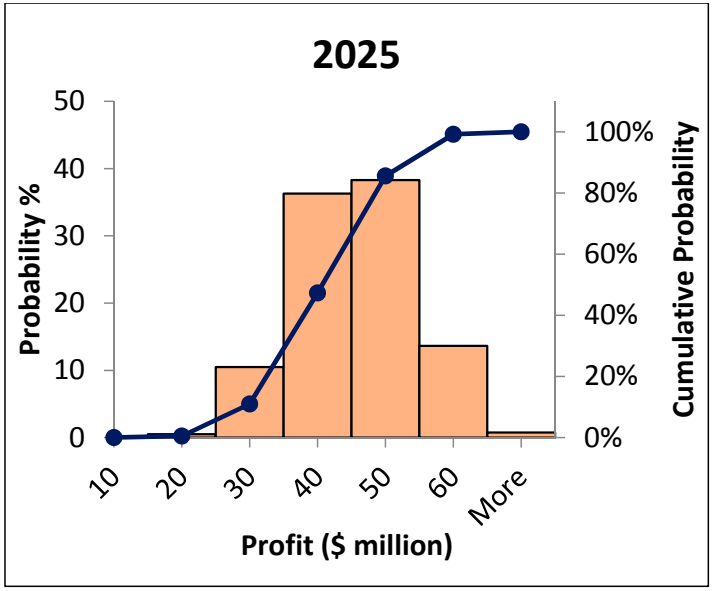

(a)

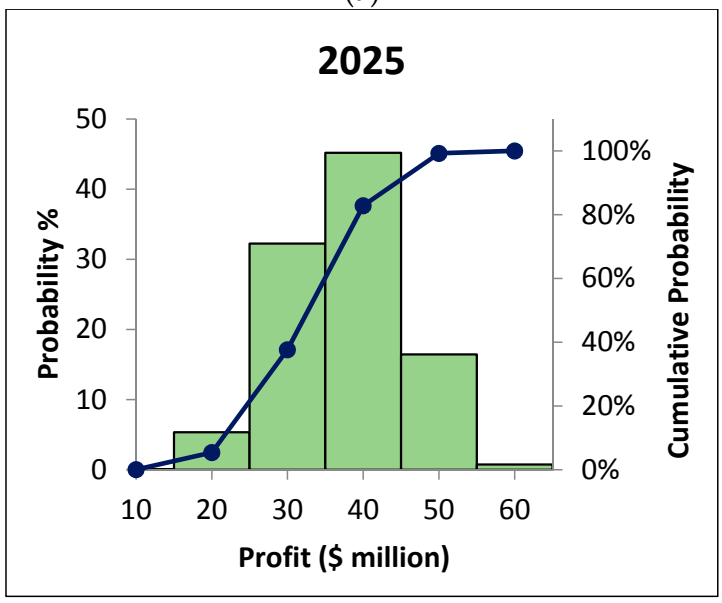

(c)

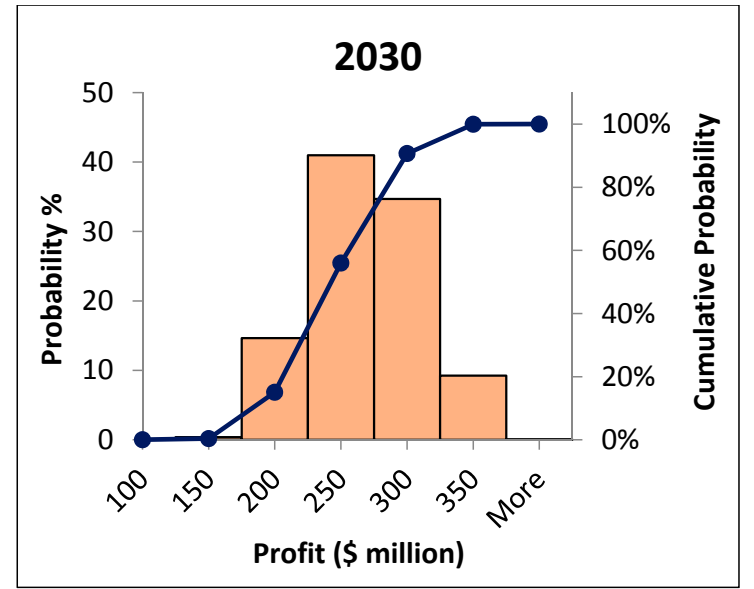

(b)

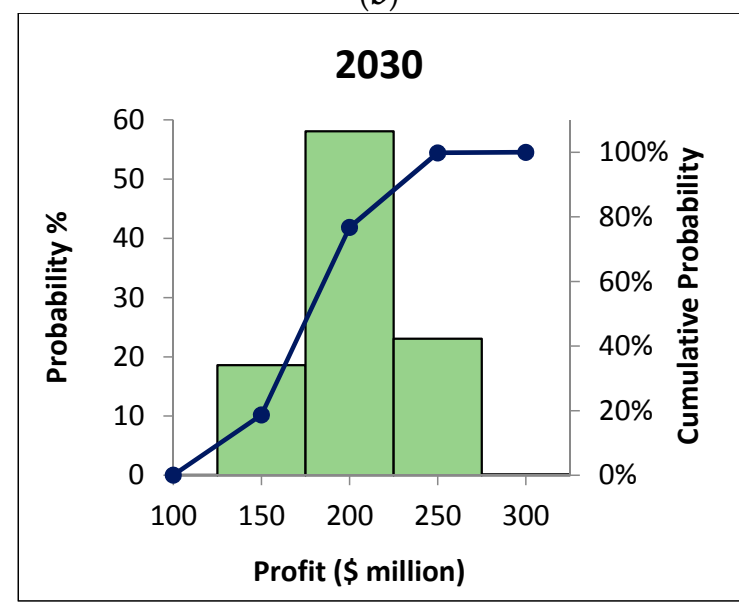

(d)

Figure 8. Histograms of profit with uncertainty: (a) and (b) base scenario for years 2025 and 2030, respectively, (c) and (d) scenario 5 for years 2025 and 2030, respectively.

Results from this study prove that government goals are achievable by 2040 under current climatic conditions. Of course, this work did not consider external stresses due to natural disasters and global and regional political and economic impacts. Different strategies are proposed for enhancing both crops area distribution and profit under sustainable agriculture development in Siwa. The methodology proposed in this study can be a significant contribution to understand and assess the development potentials of other areas of the reclamation project in the Western Desert region under similar government policies. In future work, the effect of climate change on agriculture developments needs to be studied. 


\section{Conclusions}

The Egyptian government initiated a project in 2015 to reclaim 1.5 million acres to increase agriculture production and rural resettlement from the Delta region that has high population density. This study focused on the 30,000 acres in the Siwa region within the proposed project area to identify if the government goals can be achieved under stipulated policies. It also aimed to explore possible other changes in the policy to further expand agriculture production under sustainable conditions, especially using groundwater available in NSAS. This study determined the crop area and the estimated total water use for both population and livestock under existing climatic conditions by 2040. An optimization model was used to maximize crops production. An ARIMA model was applied to predict sell prices and production costs of cultivated crops, such that profit from the project can be estimated.

The results show that only 17,010 acres can be cultivated in Siwa under the proposed government policies, which represents $56.7 \%$ of the planned area. Required crop areas in winter and summer are 7154 and 6629 acres, respectively. The estimated total water use is $40.6 \mathrm{MCM}$, which is a summation of irrigation water, domestic water use, and water requirement of livestock. Crop area and total water use were compared with available land of 17,010 acres and available groundwater from NAS which is $88 \mathrm{MCM}$, respectively. The comparison shows that there is available capacity of land and groundwater in Siwa. As a result, optimization analysis was used to maximize crop production under stipulated government policies. Different scenarios were also proposed by relaxing some of the government policies to further increase agriculture production. The results from these scenarios show that the available land area can be cultivated in the winter but not in the summer, due to high crop water demand for summer crops.

The ARIMA model was used to develop models that can predict crop sell prices and production costs for the next 10 years. The results indicate that, to maximize production, scenario 4 is recommended, which has a total production of 138,146 tons, while the corresponding production from strategic crops is 64,153 tons. This scenario has the highest cumulative profit from 2020 to 2030 , which is $\$ 755.2$ million. However, to maximize production from strategic crops regardless of profit compared with the base scenario, scenario 5 is recommended, where the production of strategic crops is 73,857 tons, and the corresponding cumulative profit is $\$ 547$ million. Scenario 4 represents the condition of relaxing crop water use and mixing water from NAS with water from PNA. Scenario 5 is the same as 4, except the change of land distribution is $80 \%$ for strategic crops and $20 \%$ for cash crops.

The uncertainty analysis considering sell prices and production costs of cultivated crops shows that the profits are about $1.3 \%$ higher than the estimated values without uncertainty. This result indicates a low risk in the estimated profits.

In conclusion, the findings from this study show that there is available capacity in Siwa that can be used for future expansion to address the national deficit in the strategic crop production of Egypt. Optimization analysis is a good tool to understand the true potential of the region with selected uncertainty analysis to address price and cost uncertainty. One distinct advantage of this study is that the results highlight a methodology that can be easily used in other parts of the Western Desert as the project expands with time, to ensure the full potential of investment is realized.

Author Contributions: Conceptualization, N.H.M. and J.J.K.; Data curation, N.H.M.; Formal analysis, N.H.M.; Methodology, N.H.M. and J.J.K.; Resources, J.J.K.; Software, N.H.M.; Supervision, J.J.K.; Writing—original draft, N.H.M.; Writing-review \& editing, N.H.M.; and J.J.K.; funding acquisition, N.H.M. and J.J.K. All authors have read and agreed to the published version of the manuscript.

Funding: This work was funded by Cultural Affairs and Missions Sector, Ministry of Higher Education, Egypt and Utah Water Research Laboratory, Utah State University.

Conflicts of Interest: The authors declare no conflict of interest. 


\section{References}

1. El-Din, M.M.N. Proposed Climate Change Adaptation Strategy for the Ministry of Water Resources E Irrigation in Egypt; UNESCO: Cairo, Egypt, 2013. Available online: http://www.eeaa.gov.eg/portals/0/eeaaReports/ CCRMP/7.CCWaterStrategy/CCFinalSubmitted8-March2013AdptStrtgy.pdf (accessed on 10 May 2017).

2. CAPMAS. Egypt in Figures, Central Agency for Public Mobilization and Statistics, Egypt. 2018. Available online: https://www.capmas.gov.eg/Pages/StaticPages.aspx?page_id=5035 (accessed on 25 November 2019).

3. Gleick, P.H. The World's Water 2002-2003: The Biennial Report on Freshwater Resources; Isl. Press: Washington, DC, USA, 2002.

4. CAPMAS. Annual Bulletin of the Movement of Production, Foreign Trade \& Available for Consumption of Agricultural Commodities, Cent. Agency Public Mobilization Stat. Cairo, Egypt. 2017. Available online: https://www.capmas.gov.eg/Pages/Publications.aspx?page_id=5104\&Year=23426 (accessed on 10 December 2019).

5. NWRP. Water for the Future: National Water Resources Plan for Egypt-2017; Ministry of Water Resources and Irrigation: Cairo, Egypt, 2005. [CrossRef]

6. CEDARE. Regional Strategy for the Utilization of the Nubian Sandstone Aquifer System; International Fund for Agricultural Development (IFAD): Rome, Italy, 2001; Volume I.

7. Bakhbakhi, M. Nubian Sandstone Aquifer System. In Non-Renewable Groundwater Resources: A Guidebook on Socially-Sustainable Management for Water-Policy Makers; Foster, S., Loucks, D.P., Eds.; UNESCO: Paris, France, 2006; pp. 75-81.

8. Abdulaziz, A.M.; Faid, A.M. Evaluation of the Groundwater Resources Potential of Siwa Oasis Using Three-Dimensional Multilayer Groundwater Flow Model, Mersa Matruh Governorate. Egypt Arab. J. Geosci. 2015, 8, 659-675. [CrossRef]

9. Moghazy, N.H.; Kaluarachchi, J.J. Assessment of groundwater resources in Siwa Oasis, Western Desert, Egypt. Alexandria Eng. J. 2020, 59, 149-163. [CrossRef]

10. MALR. National Project for Reclamation of 1.5 Million Acres in Egypt; Ministry of Agriculture and Land Reclamation: Cairo, Egypt, 2015.

11. Research Institute for Groundwater (RIGW). Report about the Groundwater in Siwa and the Future Development Plans; National Water Research Center, Ministry of Water Resources and Irrigation: Cairo, Egypt, 2015.

12. Lutz, A.; Thomas, J.M.; Keita, M. Effects of Population Growth and Climate Variability on Sustainable Groundwater in Mali, West Africa. Sustainability 2011, 3, 21-34. [CrossRef]

13. AbuZeid, K.M.; Elrawady, M.H. Sustainable Development of Non-Renewable Groundwater. In Proceedings of the International Conference on Water Scarcity, Global Changes, and Groundwater Management Responses, Irvine, CA, USA, 1-5 December 2008; University of California: Irvine, CA, USA, 2008.

14. Sharma, R.K.; Sankhayan, P.L.; Singh, R. Analysis of Profitability and Risk in New Agriculture Using Dynamic Non-Linear Programming Model. J. Agric. Sci. 2010, 2, 59-71. [CrossRef]

15. Rashed, H. Change Detection in Land Degradation and Environmental Hazards Sensitivity in Some Soils of Siwa Oasis, Egypt. J. Soil Sci. 2016, 56, 433-451. [CrossRef]

16. RIGW. Report of Groundwater Potential and Total Extraction from Different Locations in Egypt; Ministry of Water Resources and Irrigation: Cairo, Egypt, 2012.

17. MWRI. Reference Conditions for the Project of 1.5 Million Acres in Egypt; Ministry of Water Resources and Irrigation: Cairo, Egypt, 2015.

18. ARC. Proposed Crops Distribution for the Project of 1.5 Million Acres in Egypt; Ministry of Agriculture and Land Reclamation: Giza, Egypt, 2016.

19. ECDC. Booklet of Terms and Conditions for Lands in the Project of 1.5 Million Acres, Egypt. 2016. Available online: https://elreefelmasry.com/advertisement/single/30 (accessed on 15 February 2020).

20. CAPMAS. Egypt in Figures Book, Cent. Agency Public Mobilization Stat. Cairo, Egypt. 2017. Available online: http://www.capmas.gov.eg/Pages/Publications.aspx?page_id=5104\&Year=22989 (accessed on 5 July 2019).

21. Araújo, G.G.; Voltolini, T.V.; Chizzotti, M.L.; Turco, S.H.; Carvalho, F.F. Water and small ruminant production. Rev. Bras. Zootec. 2010, 39, 326-336. [CrossRef]

22. FAOSTAT. Statistical Databases: Food Balance Sheet, Egypt Country; FAO: Rome, Italy, 2017; Available online: http://www.fao.org/faostat/en/\#data/FBS (accessed on 10 June 2019). 
23. CAPMAS. Annual Bulletin of Statistical Crop Area and Plant Production, Central Agency for Public Mobilization and Statistics, 2017. Available online: https://www.capmas.gov.eg/Pages/Publications.aspx? page_id=5104\&Year=23439 (accessed on 10 August 2019).

24. Shata, H.F.A.; Ebrahem, M.A. An Econome Analysis for the Fodders Gap in Egypt. J. Agric. Econ. Soc. Sci. 2014, 5, 1039-1062.

25. Bates, G. Corn Silage; The University of Tennessee, Institute of Agriculture, Agricultural Extension Service: Tennessee, TN, USA, 2002; Available online: https://extension.tennessee.edu/publications/Documents/sp434d. pdf (accessed on 10 March 2020).

26. Lauer, J.; Agronomist, C. The Relationship between Corn Grain Yield and Forage Yield: Effect of Moisture; Hybrid and Environment; University of Wisconsin: Madison, WI, USA, 2006.

27. HBRC [Housing and Building National Research Center]. Egyptian Code for Design and Construction of Water and Wastewater Pipe Networks; Ministry of Housing, Utilities and Urban Communities: Cairo, Egypt, 2010.

28. Lardy, R.; Stoltenow, G.; Johnson, C. Livestock and Water [AS-954]; North Dakota State University Fargo: Grand Forks, ND, USA, 2008.

29. Leeson, J.D.; Summers, S. Commercial Poultry Nutrition, 3rd ed.; Nottingham University Press: Nottingham, UK, 2008.

30. Allen, M.; Pereira, R.G.; Raes, L.S.; Smith, D. Crop Evapotranspiration: Guidelines for Computing Crop Water Requirements; FAO: Rome, Italy, 1998; p. 300. Available online: http://www.fao.org/3/x0490e/x0490e00.html (accessed on 5 January 2019).

31. Doorenbos, W.O.; Pruitt, J. Guidelines for Predicting Crop Water Requirements; FAO: Rome, Italy, 1992.

32. Hillel, D. Small-Scale Irrigation for Arid Zones: Principles and Options; FAO: Rome, Italy, 1997.

33. Irmak, D.E.; Odhiambo, S.; Kranz, L.O.; Eisenhauer, W.L. Irrigation Efficiency and Uniformity, and Crop Water Use Efficiency; University of Nebraska: Lincoln, RI, USA, 2011; Available online: Https://Digitalcommons.Unl. Edu/Cgi/Viewcontent.Cgi?Article=1455\&Context=Biosysengfacpub (accessed on 4 March 2020).

34. Bai, S.; Kang, Y.; Wan, S. Winter wheat growth and water use under different drip irrigation regimes in the North China Plain. Irrig. Sci. 2020, 38, 321-335. [CrossRef]

35. Mostafa, H.; El-Nady, R.; Awad, M.; El-Ansary, M. Drip irrigation management for wheat under clay soil in arid conditions. Ecol. Eng. 2018, 12, 35-43. [CrossRef]

36. Thabet, M. Drip irrigated Barley (Hordeum vulgare L.) in arid regions of South Tunisia: Plant Growth and Yield Parameters, Turkish. J. Agric. Food Sci. Technol. 2016, 4, 470-475. [CrossRef]

37. Kirnak, H.; Dogan, E.; Türkoğlu, H. Effect of drip irrigation intensity on soybean seed yield and quality in the semi arid Harran plain, Turkey, Spanish. J. Agric. Res. 2010, 8, 1208-1217. [CrossRef]

38. Miyauchi, Y.; Isoda, A.; Li, Z.; Wang, P. Soybean cultivation on desert sand using drip irrigation with mulch. Plant Prod. Sci. 2012, 15, 310-316. [CrossRef]

39. Elnashar, Y.W. Improving Irrigation Water Management in Delta of Egypt. IOSR J. Electr. Electron. Eng. 2013, 5, 45-55. [CrossRef]

40. Daghighi, A.; Nahvi, A.; Kim, U. Optimal Cultivation Pattern to Increase Revenue and Reduce Water Use: Application of Linear Programming to Arjan Plain in Fars Province. Agriculture 2017, 7, 73. [CrossRef]

41. Zare, M.; Koch, M. Optimization of Cultivation Pattern for Maximizing Farmers' Profits under Land and Water Constraints by Means of Linear-Programming: An Iranian Case Study. In Proceedings of the 11th International Conference on Hydroscience \& Engineering, Hamburg, Germany, 28 September-2 October 2014; Bundesanstalt für Wasserbau: Karlsruhe, Germany, 2014. ISBN 978-3-939230-32-8.

42. Reca, D.; Trillo, J.; Sánchez, C.; Martínez, J.A.; Valera, J. Optimization model for on-farm irrigation management of Mediterranean greenhouse crops using desalinated and saline water from different sources. Agric. Syst. 2018, 166, 173-183. [CrossRef]

43. Jackson, R.P.; Julander, W.L. Runoff and Water Quality from Three Soil Landform Units on Mancos Shale. J. Am. Water Resour. Assoc. 1982, 18, 995-1001. [CrossRef]

44. Maas, G.J.; Hoffman, E.V. Crop Salt Tolerance-Current Assessment. J. Irrig. Drain. Div. Am. Soc. Civ. Eng. 1977, 103, 115-134.

45. Ayers, D.W.; Westcot, R.S. Water Quality for Agriculture; FAO: Rome, Italy, 1985.

46. EAS. Bulletin of Statistical Cost Production and Net Return; Economic Affairs Sector, Ministry of Agriculture and Land Reclamation: Cairo, Egypt, 2017. 
47. Gad, M.A.; Eissa, S.M.; Mahmoud, E.M. Economic evaluation of palm production in projects of young graduates in new lands. Arab Univ. J. Agric. Sci. 2013, 21, 27-40.

48. EAS. Bulletin of Statistical Cost Production and Net Return; Ministry of Agriculture and Land: Cairo, Egypt, 2017.

49. CAPMAS. Annual Bulletin of Estimates of Income from the Agricultural Sector; Central Agency for Public Mobilization and Statistics: Cairo, Egypt, 2017. Available online: https:/www.capmas.gov.eg/Pages/ Publications.aspx?page_id=5104\&Year=23466 (accessed on 5 August 2019).

50. Okagbue, H.I.; Edeki, S.O.; Opanuga, A.A. A Monte Carlo Simulation Approach in Assessing Risk and Uncertainty Involved in Estimating the Expected Earnings of an Organization: A Case Study in Nigeria. Am. J. Comput. Appl. Math. 2014, 4, 161-166. [CrossRef]

51. Clark, J.; Reed, V.; Stephan, M. Using Monte Carlo Simulation for a Capital Budgeting Project, Management Accounting Quarterly; Institute of Management Accountants: New Jersey, NJ, USA, 2010; pp. 20-31.

52. Khader, A.I. Value of Information in Design of Groundwater Quality Monitoring Network under Uncertainty. Ph.D. Thesis, Utah State University, Logan, UT, USA, 2012.

(C) 2020 by the authors. Licensee MDPI, Basel, Switzerland. This article is an open access article distributed under the terms and conditions of the Creative Commons Attribution (CC BY) license (http://creativecommons.org/licenses/by/4.0/). 